\title{
Mitigation of diffuse water pollution from agriculture in England and China, and the scope for policy transfer
}

\author{
Laurence Smith ${ }^{1}$, Alex Inman ${ }^{1}$, Xin Lai ${ }^{3}$, Haifang Zhang ${ }^{3}$, Meng Fanqiao ${ }^{4}$, Zhou Jianbin ${ }^{5}$, Sean \\ Burke $^{6}$, Clive Rahn ${ }^{7}$,Giusippina Siciliano ${ }^{1}$, Philip, M. Haygarth ${ }^{2}$, Jessica Bellarby ${ }^{2}$, Ben Surridge ${ }^{2}$ \\ ${ }^{1}$ Centre for Development, Environment and Policy, SOAS, University of London, WC1H 0XG, UK \\ ${ }^{2}$ Lancaster Environment Centre, Lancaster University, Lancaster, LA1 4YQ, UK \\ ${ }^{3}$ Agro-Environmental Protection Institute, Ministry of Agriculture, Tianjin, PRC \\ ${ }^{4}$ College of Resources and Environmental Sciences, China Agricultural University, Beijing, PRC \\ ${ }^{5}$ College of Natural Resources and Environment, Northwest A\&F University, Yangling, PRC \\ ${ }^{6}$ British Geological Survey, Keyworth, Nottingham, NG12 5GG, UK \\ ${ }^{7}$ Warwick Crop Centre, University of Warwick, Wellesbourne, Warwick CV35 9EF.
}

Corresponding author: Laurence Smith, email: I.smith@soas.ac.uk, Tel: 02030738328 ,

Centre for Development, Environment and Policy, SOAS, University of London, WC1H OXG, UK

\section{Highlights:}

- Policy framework for mitigation of diffuse water pollution from agriculture defined

- Constraints to policy transferability defined and evaluated

- Options for regulation, incentive payments, advice and voluntary action

- Extension-led diffuse water pollution mitigation strategies recommended

\begin{abstract}
This paper evaluates the existing policy frameworks for mitigation of diffuse water pollution from agriculture (DWPA) in England and China. With reference to a conceptual model of the process of policy transfer or international lesson drawing, and possible constraints to this, it assesses whether and how China can draw lessons to improve current policy from the supra-national and national provisions of the EU and a member state that by 2016 had comprehensively implemented EU agricultural and environmental policy. DWPA is first analysed as a public policy challenge to inform specification of a generic framework for its mitigation. The current policy frameworks for mitigation of DWPA in England and China are evaluated, and their potential for improvement is assessed. A number of barriers to lesson drawing for regulation, incentive payments schemes and advice provision are diagnosed. These barriers are potentially least in relation to advice provision and its use to promote voluntary action by farmers. Given its structure and capabilities the public agricultural extension system in China is also recognised as a key resource. A focus on three policy approaches to mitigate DWPA in China is recommended: $i$ ) targeted regulation to a 'reference level' of large intensive livestock, and ultimately other large commercial farms; ii) strategic use of incentive payment schemes to protect water resources from DWPA; and iii) reorientation of the ethos and modalities of operation of the extension system, informed by international lesson drawing, with the aim of rebalancing farm productivity and environmental protection.
\end{abstract}

Key words: diffuse, water, pollution, agriculture, policy, mitigation.

\section{Introduction}

Water pollution from agriculture and its consequences are a source of increasing concern (Vorosmarty et al., 2010). In England the leading pollutants from agriculture and wastewater are sediment, chemicals, nitrate and phosphorus (Gov.UK, 2016a). Projected improvement in compliance with European Union (EU) Water Framework Directive (WFD; CED, 2000) standards for 'good status' seem modest in rising from only $17 \%$ of all waterbodies in 2015 to $25 \%$ in 2021 , but physical modifications of waterbodies are a common reason for 'failure'. In contrast, $82-88 \%$ of 
the chemical and biological parameters monitored should be at 'good status' or better in all areas by 2021 (Gov.UK, 2016a). In China water pollution remains severe with more than $61 \%$ of groundwater and $28 \%$ of surface waters in the main river basins classified as unfit for human use or contact (China Water Risk, 2015). Agriculture is a major cause, estimated to be the source for $57 \%$ of the nitrogen and $69 \%$ of the phosphorus entering Chinese watercourses (MEP, 2010).

Point source ${ }^{1}$ water pollution can be mitigated by pre-discharge treatment of wastewater subject to the right regulation, technology, and political will (Smith et al., 2015a). When control has been at least partially achieved policy emphasis shifts to diffuse pollution for which agriculture is a significant source. However, diffuse water pollution is more difficult to mitigate as it consists of the releases of diverse pollutants from dispersed sources across the landscape including run off and leaching from fields and farmyards.

The challenges and conditions for agriculture and water resource management in China are unique and there is no 'model country' to provide a reference point for policy solutions; however, large federal countries such as the United States and Australia, and supra-national bodies such as the European Union can provide applicable lessons (World Bank, 2006), subject to analysis of how these might transfer with appropriate modification. Such detailed analysis is lacking in relation to DWPA. In 2016, England (as part of the UK) is representative of an EU member state that has comprehensively implemented EU agricultural and environmental policy ${ }^{2}$. This paper evaluates the policy framework for mitigation of DWPA in such an EU member state in comparison to that in China; providing an original assessment of the potential for international lesson drawing ${ }^{3}$.

The assessment proceeds by first adopting a conceptual model for the process of lesson drawing and identification of constraints to this. It then analyses the policy challenge of DWPA to derive a generic framework for its mitigation. The characterisation and validity of this framework is further established by evaluation of policy in England (supported by other OECD country examples) and equivalent policy in China. The conceptual model for policy transfer is then applied to review the potential for an improved policy framework in China and conclusions are drawn.

\section{Methods and materials}

Preparation of this paper employed review and analysis of literature and secondary data. This was supplemented by semi-structured interviews with key informants in England and China, field visits to four farming systems in China, and workshops with stakeholders in each of those locations, and with national stakeholders in Beijing. The local workshops were attended by community leaders, farmers, large farm managers, local researchers and government officers, including representatives of the public agricultural extension service (PAES) at administrative levels from village to county and city. The workshops were part of a wider project investigating nutrient management in Chinese agriculture and associated risks of DWPA. The farming systems visited in China were: rice-wheat farms near Lake Tai in Jiangsu Province; maize-wheat farms in Huantai County, Shandong Province; solar greenhouses for horticultural crops near Yangling, Shaanxi Province; and kiwi fruit and maize growers in Zhouzhi, Shaanxi Province.

\section{A conceptual model for lesson drawing}

The concept of lesson drawing or policy transfer is a domain of public policy analysis (e.g. Dolowitz and Marsh, 1996, 2000; Evans 2009; Benson and Jordan, 2011). It can be understood as the

\footnotetext{
${ }^{1}$ A discrete and discernible source of wastewater such as pipes, ditches and channels.

${ }^{2}$ Noting that the UK referendum result of $23^{\text {rd }}$ June 2016 prompts UK withdrawal from the EU. This paper focuses on England rather than the UK because of differences in policy in Scotland, Wales and N. Ireland.

${ }^{3}$ The bilateral research and knowledge exchange for this paper can be seen as a part of the 'soft' policy transfer (see definition below) conducted by the Sustainable Agricultural Innovation Network (SAIN, 2016) and inspired by common challenges, needs and aspirations for sustainable agriculture in the UK and China.
} 
process through which knowledge of policies, administrative arrangements and institutions in one jurisdiction can be used in the development of similar features in another (Dolowitz and Marsh, 2000). As in Figure 1 and Table 1, the process of lesson drawing can be analysed in stages (Benson, 2009; Rose, 2005). Figure 1 infers possible constraints to the transferability of lessons, which are identified and posed as questions and indicators in Table 1. Many of the constraints are associated with 'hard' policy transfer, i.e. adoption by the public sector based on formalised peerto-peer information exchange (Benson, 2009). This contrasts to 'soft' transfers occurring flexibly via exchange of norms, knowledge and techniques by a diverse range of actors and processes. The latter may be less constrained but typically more concerned with how best to implement a given policy or programme than its functional objective (Benson, 2009).

\section{position - Figure 1: Stages of lesson drawing.}

Source: Benson, 2009.

position - Table 1: Constraints to lesson drawing

Source: adapted from Benson 2009; Dolowitz and Marsh, 2000.

\section{The policy challenge of diffuse water pollution from agriculture}

As a 'market-failure' displaying public good and externality properties DWPA is challenging for public policy (Weersink and Livernois, 1996; Smith and Porter, 2010; OECD, 2012). Bio-physical uncertainties and the temporal and spatial characteristics of DWPA render a solely regulatory approach costly if not impractical (OECD, 2012; Smith et al., 2015a). Complexity is exacerbated by the multi-functionality of land use, its delivery of both complementary and competing ecosystem services, and the relevant property rights of society and land owners. This applies to the activity that generates DWPA but also to some of its mitigation measures. For example, riparian buffer zones can limit pollutant runoff but also provide amenity, habitat and carbon sequestration. Furthermore, today's pollution is in large part a legacy of past farming practice, and change in practice today may not fully deliver its benefits for decades to come (Powers, et al., 2016). Consequently how all costs and benefits from agriculture and DWPA mitigation are distributed is a matter for socio-political determination. Deliberation on this is best decentralised to the level appropriate to account for existing relevant responsibilities and local specificities (Smith et al., 2015a).

\section{A mitigation framework for diffuse water pollution from agriculture}

\subsection{A common framework}

Given the characteristics of DWPA (Section 4) a range of policies for its mitigation must be considered. Regulation of farming practice can be complemented by economic incentives, provision of advice to promote voluntary action and self-regulation, and at the margin acquisition of land or control of its use (Weersink and Livernois, 1996; Shortle and Horan, 2001; Mauerhofer et al. 2013). An appropriately sequenced policy mix is likely to outperform a single instrument such as a pollution tax, especially where multiple barriers to farmer adoption of DWPA mitigation measures exist (OECD, 2012). Such barriers exist in China as identified by Smith and Siciliano, 2015. There needs to be emphasis on changing the behaviour of not only farmers but also all other stakeholders. A national approach is needed that addresses all polluters without singling out farmers. Government agencies, civil society organisations and private businesses must all take actions at scales from sub-catchments to national and transboundary (OECD, 2012). A well designed policy mix for mitigation of DWPA will facilitate coordination of actions. It must also be supported by adequate scientific understanding and evidence. We term this mixed approach, including the knowledge base that supports it, the 'mitigation framework for DWPA' (Smith and Siciliano, 2015). 

Source:

Figure 2 depicts a layered approach of complementary policies. This corresponds to current provision in England as considered in Section 6, whilst other EU and OECD countries including Australia, New Zealand and Canada also employ a regulatory approach complemented by advice, voluntary action and targeted incentives (OECD, 2010). First, enforceable regulations applied widely aim to achieve a baseline of environmental protection. This equates to the 'reference level' (Scheele, 1999) that divides environmental standards that farmers are expected to meet at their own cost from higher standards for which society is willing to provide remuneration (or at least compensation for income foregone). Meeting standards at the 'reference level' should become a 'compliance condition' to receive such remuneration (Weersink and Livernois, 1996). In increasingly targeted layers, regulations to protect water resources can then be complemented by voluntary action and incentives. Provision of advice is 'cross-cutting' as it can facilitate compliance with regulation and adoption of voluntary and incentivised measures. The national knowledge base is similarly an essential supporting resource, providing policy makers and farm advisors with information on the outcomes of DWPA mitigation measures, costs and farmer responses.

\subsection{Other policies}

\subsubsection{Water quality trading}

The mitigation framework in Figure 2 is not exclusive of other policy options. For example, water quality trading (WQT) schemes as a form of emissions trading (OECD, 2012) could be an alternative or complement to incentive payments. 'Cap and trade' schemes have the potential to limit emissions at lowest net cost to society (Choi, 2006) but are institutionally demanding for mitigation of DWPA as they require: binding regulatory limits on pollution levels; sufficient variation in pollution control costs between farms to make gains from trading possible net of transactions costs; trading rules that are simple and minimise transaction costs; and a trusted intermediary to facilitate trading (adapted from OECD, 2012). They also require the measurement of emissions, inputs or change in environmental conditions (Choi, 2006). Consequently, almost all WQT schemes are only partially capped ${ }^{4}(O E C D, 2012)$. A typical scenario is that point source polluters buy pollution reductions to achieve their regulatory compliance in the form of input use reductions made voluntarily by farms. DWPA can thus be profitably reduced by the farmer but is not capped.

Water quality may also benefit from schemes such as 'wetland banking'. In the USA under the Clean Water Act (Section 4.4) conversion of wetlands to other uses is capped to "no net loss" so that any loss must be compensated by provision of new wetlands or enhancement of existing sites. 'Wetlands banks' can create wetlands in multiple locations and sell 'wetland credits' to property developers to offset wetland loss (McKenney and Kiesecker, 2010).

\subsubsection{Pollution taxes}

A tax on emissions would best apply the polluter-pays principle to change behaviour, but given the costs of monitoring DWPA the 'second-best' policy of a tax on the inputs that cause emissions is usually a default (Lally et al, 2007). Examples include pesticide taxes in Denmark, France, Italy, Norway and Sweden and fertiliser taxes in Italy, The Netherlands, Sweden and USA (OECD, 2012). Inelastic demand for farm inputs, swapping of pollutants or pollution pathways as farming systems change, international trade competitiveness, equity for farmers already compliant with regulated input use levels and political resistance from farmers are all issues that may limit application of this policy. However, there is evidence that sufficiently high tax levels supported by farm advice can achieve reductions in input use without loss of farm production (OECD, 2012).

\footnotetext{
${ }^{4}$ Input (nitrogen) trading within a cap between farmers in the Lake Taupo catchment, New Zealand provides an exception (OECD, 2012).
} 


\subsubsection{Reduction of perverse incentives from agricultural support policies}

An alternative approach to mitigation of DWPA is to remove or reduce the effect of policies that raise producer prices, subsidise use of polluting inputs or by other means encourage intensive farming. Such policies neglect variation in landscapes and may drive intensification poorly matched to environmental capacity to mitigate and absorb pollution (OECD, 2012).

\section{The mitigation framework for diffuse water pollution from agriculture in England}

\subsection{Regulation}

In England relevant regulation relates mainly to the use (storage, handling and application) of agricultural inputs (pesticides, inorganic fertilisers and manures) with the potential for negative environmental impacts. Regulations are numerous and detailed. The EU Nitrates Directive (CEC, 1991) as transposed into national legislation can be cited as a leading example. Areas where nitrate levels in water exceed, or are at risk of exceeding $50 \mathrm{mg}$ per litre, and/or are eutrophic, are designated as Nitrate Vulnerable Zones (NVZs) within which farmers are required to implement measures designed to reduce and/or prevent nitrate loss to water through leaching or run-off. Farm inspections are carried out to ensure compliance with standards that include nitrate application levels, timing of applications and adequacy of fertiliser storage.

\subsection{Voluntary action}

Some measures to mitigate DWPA may be adopted by farmers out of altruistic concern for environmental quality, but for most adoption is motivated by cost or time savings from improved practice. In England government agencies have advised farmers and partnered industry-led voluntary initiatives ${ }^{5}$ to implement environmental protection measures. Voluntary action by farmers is also motivated by the advice and technical assistance provided by non-government organisations (NGOs). Foremost in this are registered charities, including rivers trusts, wildlife trusts and other farm advisory groups ${ }^{6}$, that source funding from governmental (UK and EU) and private sources. They generally seek to develop and encourage farmer adoption of 'win-win' solutions of management improvements, cost savings and environmental protection. Examples of measures include fencing of streams, clean and dirty water separation in farmyards, and relocation of feeders, tracks and gateways. Many farmers/farm managers are also highly trained and experienced, particularly for larger commercial operations, and seen as part of agricultural knowledge and information systems $\left(\mathrm{AKIS}^{7}\right)$ are capable of innovating cost saving and environmentally beneficial practices.

\subsection{Incentive payments}

Incentive payments can take a variety of forms, but in general provide incentive (or compensation) for change in farm input use, management practice or land use that mitigates DWPA. Farmers in England can participate in a variety of schemes. Most participate in the Basic Payments Scheme (BPS) funded under the EU Common Agricultural Policy (CAP). This provides an annual per hectare (ha) subsidy aimed to support farm incomes and maintain agricultural productivity. To receive the payment farmers must comply with 'Statutory Management Requirements' (SMRs) and 'Good Agricultural and Environmental Conditions' (GAECs) that relate to public, animal and plant

\footnotetext{
${ }^{5}$ Three leading examples are: the Campaign for the Farmed Environment (CFE), the Voluntary Initiative (VI), and the Tried \& Tested initiative.

${ }^{6}$ For example, LEAF (Linking Environment and Farming).

${ }^{7}$ Defined as the organizations, institutions and actors that generate and exchange information to enhance farmer knowledge and skills, with the aim of enabling them to co-produce new knowledge and solutions (EU SCAR, 2012).
} 
health, environment, climate change, good agricultural condition of land and animal welfare (Defra, 2016). Known as cross-compliance, this includes a set of basic measures to protect watercourses and groundwater against pollution, soil erosion and over abstraction ${ }^{8}$. Farmers have incentive to adopt these measures as failure to do so can result in loss of some or all of the BPS payment (though this is subject to the effectiveness of monitoring and enforcement).

Many farmers can also access payments under the rural development policy of the CAP. In England payments are offered by the Countryside Stewardship (CS) scheme ${ }^{9}$. This incentivizes farmers to adopt measures and provide environmental goods beyond those required by the crosscompliance and greening rules ${ }^{8}$. Unlike its predecessor schemes ${ }^{9}$ most options in the CS scheme are competitive. Targeting and scoring of applications from farmers aims to encourage applications well-matched to local environmental priorities ${ }^{10}$ (NE, 2015). The overarching scheme priority "is to protect and enhance the natural environment, in particular the diversity of wildlife (biodiversity) and water quality' (NE, 2015, pp. 3). Provision is made for: 'Mid-Tier' multi-year agreements for widely applicable environmental improvements including management options and capital grants; 'Higher Tier' more targeted multi-year agreements for environmentally significant sites, commons and woodlands requiring complex management; and 'Capital Grants' for hedgerows and boundaries, improving water quality, developing implementation plans, feasibility studies, and woodland creation and improvement (NE, 2015). The 'Mid-Tier' includes the specific aim to reduce DWPA and applicants can select from a number of relevant management options, plus items eligible for capital grants ${ }^{11}$.

Aside from publicly funded schemes, UK policy makers have encouraged ${ }^{12}$ the private sector to invest in water resource protection through payments for ecosystem services (PES) ${ }^{13}$. The leading examples to date are investment by water companies in farm management measures that enhance water retention in uplands and protection of water quality in drinking water source areas ${ }^{14}$. Investments are motivated by ability to demonstrate value for water customers and shareholders. Such initiatives were only recently facilitated by reforms by the water industry regulator that permit water company investments on land owned by private landowners and investment appraisal over a sufficiently long time horizon to capture benefits (compared for example to investment in water treatment solutions). Beyond water companies, significant PES investment by the private sector is likely to remain limited without further reform of relevant fiscal and regulatory frameworks to provide the necessary commercial incentives.

\footnotetext{
${ }^{8}$ Since 2015, farmers with land above set thresholds also have to meet 'greening' rules to receive a 'greening payment' making up about $30 \%$ of their total BPS payment. Requirements for this make little direct provision for water resource protection, although riparian buffer strips can qualify under a requirement for ecological focus areas (EFAs); e.g. buffer strips, catch crops, cover crops, fallow land, hedges and nitrogenfixing crops (RPA, 2016).

9 This superceded three previous schemes from January 2016: the Environmental Stewardship scheme; the English Woodland Grant Scheme; and capital grants from the Catchment Sensitive Farming (CSF) programme. CSF is a project run by Natural England in partnership with the Environment Agency and the Department for Environment, Food and Rural Affairs. It raises awareness of DWPA by giving free training and advice to farmers in selected priority catchments in England. Grants were also provided for a variety of works including infrastructure for clean and dirty water separation, track maintenance, watercourse fencing, roofing of manure storage and resurfacing of gateways.

${ }_{10}$ As set out in regional statements of priorities (Gov.UK, 2016b).

11 'Water quality grants' are only available in priority catchments identified in the CSFprogramme.

12 Publication of Smith et al., 2013, provides an example.

${ }^{13}$ Wunder (2008, pp. 835) defines PES as "(a) a voluntary transaction where (b) a well-defined environmental service (ES) or a land use likely to secure that service (c) is being 'bought' by a (minimum one) service buyer (d) from a (minimum one) service provider (e) if and only if the service provider secures service provision (conditionality)".

${ }^{14}$ E.g. Upstream Thinking (2016).
} 
Incentive payments to farmers in England have usually been based on individual contracts, whereas payments to communities or groups of farmers could help ensure that individual actions best complement the actions of others in production of ecosystem services at a necessary scale, for example, comprehensive water quality protection throughout a hydrological sub-catchment. Such environmental stewardship as a community rather than individual responsibility may also promote advantageous social learning, self-monitoring and regulation, and partnership working. In England a small number of multi-actor agreements have been in place ${ }^{15}$, for example, to manage overgrazing on moorland in South West England. Here farmers formed a limited company which receives funds for distribution to members and assumes responsibility to ensure members adhere to the environmental management requirements of the agreement. Such examples remain rare. They can incur considerable time and transaction costs to set up and may require additional incentives for farmers (premium payments or threat of regulatory control), as UK farmers do not generally have experience of such collaboration.

\subsection{Advice provision}

Since the mid-1980s production oriented farm management advice has been treated by successive governments as a private good to be provided by competitive commercial suppliers (Garforth et al., 2003). State funded farm advice originally focused on farm productivity but has increasingly adopted an environmental protection agenda. Public provision in England now takes the form of the Farming Advice Service (FAS) which is delivered by a network of contracted independent advisors. It provides advice on the BPS, cross-compliance and 'greening requirements', other environmental regulations, nutrient management and climate change adaptation and mitigation. Advice is delivered via on-line information, articles in the farming press, workshops, farm walks and drop-in-clinics (Gov.UK, 2016c). The CSF$^{9}$ programme has primarily distributed grants for on-farm capital works that protect water resources but CSF advisors also provide farmers with pollution mitigation advice in 77 priority catchments.

A range of private and civil society organisations also provide advice, and both FAS and CSF work in partnership with other voluntary initiatives such as the CFE ${ }^{5}$, and organisations such as the National Farmers Union, Country Land and Business Association, Agricultural Industries Confederation (AIC) and rivers and wildlife trusts. In England agricultural knowledge and information systems can thus be characterised as highly diverse and decentralised. There are at least 80 sources of advice to land managers (Defra, 2013a, p.4; Prager and Thompson, 2014, p.8) from "at least 14 different types of actor" (Curry et al., 2012, p.244). However, it is a subset of these led by CSF and rivers trusts that possesses most in-depth expertise related to DWPA. The AIC and its Fertiliser Advisers Certification \& Training Scheme (FACTS) are also notable. This voluntary scheme sets standards, provides training and accredits advisers who provide nutrient management advice. Growth to over 2500 qualified advisers in the UK demonstrates demand by farmers for reliable advice to optimise crop nutrition whilst protecting soil, water, air and biodiversity (BASIS, 2016).

\subsection{Knowledge base}

For farm typologies in England there is a body of evidence for the effectiveness of DWPA mitigation measures at a field scale (Newell Price et al., 2011 ${ }^{16}$; Cuttle, et al., 2016). Although this could be further improved (Randall, et al., 2015; Holden, et al., 2016), it is informing implementation of the national mitigation framework. Knowledge of catchment scale responses to mitigation measures is subject to greater uncertainty. On-going research through 'demonstration test catchments' is addressing this (McGonigle, et al., 2014), and novel spatial environmental science and modelling approaches are being used to assess pollution risks, pressures and

\footnotetext{
${ }^{15}$ Formed under the Environmental Stewardship scheme prior to 2016.

${ }^{16}$ An inventory of methods and user guide for selection of farm-level mitigation options to reduce DWPA, air pollution and greenhouse gas emissions.
} 
mitigation strategies at a catchment scale (Holden, et al., 2016). Guidance and case studies have

\subsection{Other policies}

WQT schemes and pollution taxes are not active policies for DWPA mitigation in England. With regard to perverse incentives, the BPS is 'decoupled' from production incentives though it can be argued that any farm income support is fungible and may still contribute to intensification. However, it has also been directly observed by the authors that financially marginal and undercapitalised farms are often among the worst polluters; at least in the dairy sector.

\subsection{Evaluating the effectiveness of the mitigation framework for diffuse water pollution from agriculture in England: synergies, conflicts, deficiencies and collective action}

The responsible authorities are deliberately parsimonious in enforcement of farm regulation, stemming from caution given the evidential costs of legal prosecution and a lack of political support for a 'heavy-handed' approach (key informants). In 2012, the National Audit Office concluded that the inspection regime by multiple agencies was lacking in coordination and burdensome for compliant farmers. Their evaluation was hindered by the lack of coordinated monitoring across inspections and outcomes, but it was concluded that the regime was not cost effective or 'value for money' (NAO, 2012). Table 2 summarises farm inspections relevant to Figure 2 and Section 6. Only a small proportion of farms are likely to receive such inspections ${ }^{17}$ (NAO, 2012). It can be concluded that the effectiveness of regulation to ensure the 'reference level' (Figure 2) for mitigation of DWPA can be improved.

\section{position -Table 2: Farm inspections in England relevant to mitigation of diffuse water pollution from agriculture, 2011-2012 \\ Source: Defra, 2013b}

Defra is seeking to improve data sharing and coordination of farm inspections between its agencies (Defra, 2013b). An 'earned recognition approach' (Table 2) also aims to reduce inspection burdens for compliant farmers recognised as 'low risk businesses' from their record of inspections and their participation in voluntary assurance schemes. Approximately $40 \%$ of farmers receive inspections to qualify for membership of non-government food standard and supply chain assurance schemes (NAO, 2012). Defra thus expects to improve targeting of its agencies' inspections to those farms where the risks of non-compliance are highest.

Evidence for the effectiveness of voluntary action by farmers to mitigate DWPA is lacking as NGOs (and government agencies) typically lack resources for evaluation studies (or prefer to prioritise expenditure on actions). However, the available evidence is largely positive. A leading example is provided by the Cornwall Rivers Project (CRP). Implemented by the Westcountry Rivers Trust (WRT) from 2002 to 2006 at a cost of $£ 2.6$ million this project provided 'tailored' advice to 870 farms covering over 56,000 ha and $1,380 \mathrm{~km}$ of watercourses. An independent economic survey reported average annual cost savings per farm from measures that mitigate DWPA of over $£ 1360$, achieving 'payback' for the project in less than 3 years (WRT, 2006). Further to this, in England 268,500 ha of voluntary environmental land management (i.e. not incentivised by payments) were achieved in 2015 (Defra, 2015a); equivalent to approximately $8.5 \%$ of the area of cereals grown in the UK in the same year (Defra, 2015b). However, this had declined from 676,700 ha in 2013 illustrating that although voluntary action can be achieved at scale its effectiveness may be limited by the fact that it is non-binding.

For incentive payments schemes to be effective in mitigating DWPA they must make good use of their limited financial resources through targeting and sustained rates of scheme participation.

\footnotetext{
${ }^{17}$ Although for all purposes over 110,000 farm inspections are made annually (NAO, 2012).
} 
Targeting requires that farmers undertake the correct actions in the correct locations for prevailing water quality problems. Recent revisions to cross-compliance and the CS scheme (Section 6.3) go some way to address past criticisms that targeting for DWPA largely failed because of weak incentives for farmers to adopt those measures with the greatest potential to deliver soil and water protection outcomes, whilst regional priority statements ${ }^{10}$ inadequately prioritised water quality protection as compared to landscape heritage and biodiversity conservation (Defra and The Rivers Trust, 2012). In particular, farmers have rarely considered the payments for DWPA mitigation measures that require partial or full land retirement in specific locations to be sufficient to offset the income foregone, particularly as they were able to adopt lower opportunity cost measures that achieved other environmental objectives (with marginal if any benefit to water protection) to qualify for the CS scheme ${ }^{18}$. It is thus important that options for mitigation of DWPA in the CS scheme are adequately prescribed, prioritised, incentivised and locally varied. CSF capital grants have been focused on DWPA and competitive for farmers, but their optimal targeting has been hindered by data deficiencies, uncertainty regarding the nature and severity of water quality problems, and limits to the time that CSF advisors can spend visiting farms and co-planning optimal measures (Defra and The Rivers Trust, 2012).

Sustaining farmer participation relates to incentives and the length of agreements. The CS scheme offers 5 year agreements for most measures, and 10 year agreements for some 'Higher Tier' measures. Both can be too short to 'lock' strategic environmental improvements into the landscape, but farmers are often reluctant to enter into longer agreements (Smith et al., 2012). UK and EU budget cycles that sustain funding also operate over 5 and 10 year cycles at most. England also lacks legal provision for agreements between a landowner and another party which place long-term restrictions on the use or management of a parcel of land (Law Commission, 2013; Smith, 2013). The Law Commission recommends introduction of conservation covenants to provide this instrument (Law Commission, 2014) but this has yet to be enacted (Law Commission, 2016).

As noted, privately funded PES schemes in England are few and mainly focus on protecting sources of drinking water. However, their existence and potential growth requires coordination with public schemes to optimise leverage of environmental benefits, avoid double-funding of measures and achieve spatial targeting. Similarly, coordination is needed with regulation, voluntary action programmes and other incentive schemes for habitats and climate change mitigation. Multiple agencies are involved, e.g.: Environment Agency, Natural England, local authorities, water companies, and NGOs; each with different priorities and working to different spatial boundaries. Also two government sponsored partnership programmes - the Catchment-Based Approach ${ }^{19}$ and Local Nature ${ }^{20}$ partnerships - address different environmental objectives and scales of management. Coordination between all entities is needed for the mitigation framework for DWPA to be as effective as possible. For example, data sharing and joint mapping can be a first step in condition and threat assessment for water bodies, leading to better aligned plans for a multifunctional landscape. Multi-stakeholder partnerships offer a means for local knowledge to inform CS scheme priorities but to date there has been little dialogue and synergy between these processes $^{21}$. Hence, the potential benefits of participation by stakeholders are not being fully captured (despite the prescriptions of Article 14 of the EU WFD; information from key informants).

\footnotetext{
18 Similarly, it is currently anticipated that under 'greening rules' qualifying EFAs can be established very flexibly on farm holdings and hence are unlikely to be well targeted to protect water resources.

19 Multi-stakeholder Catchment Partnerships for each of 83 catchments in England, tasked to generate an understanding of the water quality issues in each catchment and involve local communities in decisionmaking on solutions (Defra, 2013c).

20 Partnerships of local organisations, businesses and people that aim to improve their local natural environment (Defra, 2012).

${ }^{21}$ However, some public consultation mechanisms were used to inform design of the CS scheme.
} 
Inter-agency coordination is also important in relation to advice provision. The diverse, decentralised and privately driven advice sector that has evolved in England has strengths and weaknesses (Sutherland et al., 2013). Pluralistic providers supply choice, flexibility, competition, reduced public cost and perhaps efficiency to a heterogeneous farming sector (Garforth et al., 2003), and farmers who know what they want can access information from competent actors (Knierim and Prager, 2015). However, fragmentation, a lack of coordination and short term relationships between advisers and farmers may lead to inconsistent messages, duplication and gaps in provision, and consequently to confusion and message fatigue for farmers (AIC, 2013), and to loss of trust in the adviser from farmers (Sutherland, et al., 2013).

\section{The mitigation framework for diffuse water pollution from agriculture in China and its effectiveness}

\subsection{Regulation}

China lacks farm-level regulation and enforcement for mitigation of DWPA comparable to that in England. This is inevitable given the number and size of farms and the history of their role in economic development. However, the proportion of land farmed in larger units is rapidly increasing through land 'transfer'22 (Huang et al., 2012), and central government is strengthening higher level regulations, monitoring and enforcement to address environmental degradation. For example, stricter penalties for enterprises polluting water resources and updated national water quality standards were introduced by the 2008 Water Pollution Law. The Ministry of Environmental Protection and the Ministry of Water Resources have also enhanced their discharge and water quality monitoring, although their spatial coverage remains relatively sparse. However, 'top-down' regulatory intent is widely 'decoupled' from ability for implementation and enforcement (Marquis et al., 2011; Wang and Wang, 2011). For mitigation of DWPA this is caused by multiple multi-level factors (Smith and Siciliano, 2015). Among these is a lack of sufficiently well-defined regulations for management of soils, animal wastes and fertilisers. Central government and provinces produce guidelines (e.g. ECEGP, 2015) but these remain advisory and non-enforceable. Regulation and oversight of quality control in the manufacture of chemical fertilizers is also lacking (Li et al., 2013). Similarly in most areas there is a lack of regulations for livestock waste treatment, storage and disposal, utilization of manures, carrying capacity of land and need for riparian buffer zones (Sun et al., 2012; Li et al., 2013). For the environmental laws that do exist enforcement is inconsistent across regions and penalties are usually insufficient to ensure compliance; hence reinforced by a continuing growth-first mentality the judicial system remains largely "incapable of providing robust protection of environmental rights against abuses" (Wang and Wang, 2011, p.169).

\subsection{Incentive payments}

A variety of 'eco-compensation' programmes exist, but lesson drawing from these is weak across regions and sectors (Bennett, 2009; Zhen and Zhang, 2011), let alone internationally. Most concern provision of watershed ecosystem services from land use change in upper catchments. Compensation payments in cash and/or grain are made to farmers who take land out of crop production, with the aims of reducing deforestation, soil erosion and rural poverty rather than DWPA per se. Nonetheless leading schemes provide relevant experience and some evidence of success; for example, the Sloping Land Conversion Programme (SLCP; Xu et al., 2004a) and Grain for Green Programme (GGP; Cao et al. 2009). More water focused is the Paddy Land-to-Dry Land (PLDL) programme that aims to protect water quality and quantity for the Miyun reservoir that serves Beijing, and under which farmers are paid to convert their fields from flooded rice to dryland cropping (most opting to grow maize), reducing water consumption, and fertilizer and sediment runoff (Zheng et al., 2013). Under the SLCP at least 60 million rural households committed over 7 million ha of cropland to conversion (Xu at al, 2006) and outcomes in Yunnan Province for

\footnotetext{
22 Processes of consolidation of small and fragmented holdings through a range of rental and transfer arrangements.
} 
example, were relatively well accepted by all stakeholders in terms of environmental and distributive justice (He and Sikor, 2015). For the GGP total vegetation cover in areas covered by the project in northern Shaanxi Province increased from almost 30\% in 1998 to $42 \%$ in 2005 (Cao et al, 2009). Under the PLDL households upstream of the reservoir converted all of their rice fields with corresponding improvements in water quantity and quality and an aggregate benefit-cost ratio for the programme of 1.5 (Zheng et al., 2013).

Other scheme outcomes are mixed. Land targeting has sometimes been poor, inappropriate afforestation has reduced soil moisture and the water table, and excessive shading from trees has hindered ground cover increasing the risk of soil erosion and affecting biodiversity (Cao et al, 2009; $\mathrm{Xu}$ at al, 2006). Programme cost effectiveness has been questioned: in some areas compensation payments may have been higher that necessary to incentivise farmers; in others benefits of change to farmers have been marginal and re-conversion to prior cropping was expected once compensation phased out (Xu et al., 2004b; Xu et al, 2006; Xiaoyun et al., 2006; Bennett, 2009; Zhen and Zhang, 2011). Farmers and other stakeholders have also not been involved sufficiently in scheme design and selection of plots for conversion, contributing to sub-optimal programme delivery (Xiaoyun et al., 2006).

\subsection{Advice provision, voluntary action and knowledge base}

The scope for voluntary action by farmers to mitigate DWPA in China is limited in many arable and horticultural systems by field and farm size, income levels, prevailing knowledge, attitudes and practices (in part age and gender related), and increasingly by labour constraints (Smith and Siciliano, 2015; Smith et al., 2015b). There is more scope in confined animal feeding operations (CAFOs) and emerging large farms, but most farm decision making remains driven by an ethos to maximise food production and economic growth (Smith and Siciliano, 2015). A culture of environmental stewardship by farmers or NGOs that could promote this barely exist. There is, however, great potential to improve the efficiency of farming practice whilst maintaining productivity and reducing risk to the environment. For example, management of soils, manures, chemical fertilizer and irrigation could all be improved to more closely match crop requirements and reduce risk of losses to air and water (e.g. Chen et al., 2014; Powlson et al., 2014). This emphasises AKIS and their ability to change farmer behaviour through advice, training and access to technologies. Dominated by the PAES to date, AKIS in China are currently in an uncertain transition towards the more diverse, liberalised and networked systems observable in most developed economies (Smith at al., 2015b).

As it is large in terms of staffing and number of township 'stations', in the 'absence' of regulation and incentive schemes (Sections 7.1 and 7.2), the PAES is the leading public resource available for mitigation of DWPA. This presents both an obstacle and an opportunity. An obstacle if people, procedures and institutions are not oriented to address environmental protection and are resistant to change, but an opportunity in terms of the human and physical capacity that exists. Hence current attempts to mitigate DWPA in China must focus in large part on the capabilities of the PAES. However, many observers are critical of its status and performance. They note: low responsiveness to community and farmer needs despite strong demand for new technologies; insufficient attention to market access, information provision and information technology in remote areas; functional specialisation and 'silo-working' at Ministerial, provincial, municipal and county levels (even though at township level a single station usually implements all extension activities; Huan et al., 2010); fragmentation of stakeholders, each with varying roles, knowledge, objectives and policy instruments; and lack of coordination and scientific consensus between the PAES and universities and research institutes despite their growing role in technology development and transfer (Ma et al., 2013). The PAES exhibits an interventionist approach to agricultural modernisation based on integration of research, education and extension under the Ministry of Agriculture, and a linear model of technology transfer (from scientists to the users) (Hu et al., 2009). 
In each of the four locations visited in China (Section 2), informed by workshops with local stakeholders, the PAES was observed to be capable of disseminating information but farmers were passive recipients of recommendations with little formalized opportunity to feedback priorities and needs. Farmers surveyed often reported greater trust in neighbours and relatives than in PAES technicians (Smith, et al., 2015b). Efficiency in use of natural resources and environmental protection remain low priorities in rural areas (Smith and Siciliano, 2015) and the PAES remains strongly focused on productivity, hindering development of a coherent strategy to balance this with environmental protection. For DWPA, lacking relevant regulation and publicly available data for ground and surface water quality ${ }^{23}$, there were no 'reference levels' against which to set advice and training, or evaluate achievement. Similarly, relevant research is fragmented, lacks coordination and is not being compiled in the form of an accessible knowledge base for use by the PAES and wider AKIS. At local level the education level of extension agents is relatively low, they lack well-adapted 'messages' for mitigation of DWPA and training in modern communication methods. Overall the functional divisions and failures of PAES performance indicate that current provision is poorly equipped to meet the needs for horizontal coordination of all AKIS actors (including innovation by and feedback from farmers), and for integrated assessment, design and implementation of measures for mitigation of DWPA. However, at village and township level functions and approaches are more integrated, and despite technical capacity limitations, there may be some scope for the emergence of a more holistic approach (Smith and Siciliano, 2015). There are thus many deficiencies in the knowledgebase base needed to support the mitigation of DWPA. Universities and research institutes need to be faced with applied questions and problems delivered from the farmers and other stakeholders in order to carry out and communicate the most relevant research (Rahn, 2013); yet incentives for researchers inevitably favour high impact journal publications over knowledge transfer to farmers, whilst the Ministry of Education in China lacks bureaucratic alignment ${ }^{24}$ with the Ministries of Environmental Protection and Agriculture.

\subsection{Other policies}

As in England, WQT and pollution taxes are not active policies in China, and scope for reduction of perverse incentives from agricultural support policies is limited. Such policies include direct payments for grain production, a general subsidy for agricultural inputs, a subsidy for adoption of improved crop varieties, a farm machinery purchase subsidy, minimum grain purchasing prices, temporary storage options and some environmental protection measures (Ni, 2013). Although in aggregate the level, number and scope of farm support policies has risen, the value of support per capita and farm household remains relatively low. There are regional differences but farmers typically gain $5-6 \%$ of their income from support policies, much less than in most developed economies (OECD, 2011; Ni, 2013). Although potentially fungible, most support can also be considered decoupled from production decisions (Chen, 2011; Ni, 2013; Huang, 2014). It may also modestly inhibit more rapid transition to larger farms that have more potential for regulation, advice provision and capacity for environmental protection measures (Smith and Siciliano, 2015); although the need to address rural poverty and manage rural-urban transitions must be recognised.

590

591

In contrast to England where world market determined prices limit demand for fertilizer, the fertilizer sector in China merits reform. A policy of price caps was removed in 2009 but import tariff reductions are still used to mitigate domestic shortages and four subsidy programmes remain ${ }^{25}(\mathrm{Li}$

\footnotetext{
${ }^{23}$ For example, it was reported during a workshop in Huantai County that groundwater quality monitoring is the responsibility of the Provincial Environment Department and that data is not accessible to the County Agricultural Bureau.

24 “...the extent to which the structure of the government allows national development strategies and policies to be consistently and effectively implemented" (Marquis et al., 2011, p. 41).

${ }^{25}$ Exemption from electricity price increases for manufacturing plants; exemptions from price increases and certain charges for rail transport costs; exemption from value added tax; and a credit subsidy for enterprises providing six months storage of fertilizer as a reserve to stabilize supply (Li et al., 2013).
} 
et al., 2013). Together with the general farm input subsidy these industry subsidies provided USD 18.76 billion to the sector in 2010 ( $\mathrm{Li}$ et al., 2013). This contributes to inefficient manufacturing, variable quality and relatively low prices. For example, since the 1970 s, farmers have paid 50 to $75 \%$ less for urea fertilizer than the world market price (Li et al., 2013). This induces excessive and poorly managed use by farmers and thus to DWPA (Sun et al., 2012; Li et al., 2013).

\section{The potential for lesson drawing for mitigation of diffuse water pollution from agriculture in China}

No elements of the mitigation framework for DWPA present in England are completely absent from China and lesson drawing must consider what can be better developed rather than what could commence. Table 3 attempts a first high level assessment of the questions and indicators from Table 1 (this could be broken down into more detail for specific policy components).

\section{position - Table 3: Assessment of lesson drawing for mitigation of diffuse water pollution from agriculture in China}

With regard to regulation there is growing public demand for improvements in environmental quality in China (e.g. Economist, 2014), although the advocacy role of civil society is limited by the political restrictions placed on the activities of non-governmental actors. Central pronouncements signal the aim of 'green development' (protecting the environment and pursuing environmentally friendly economic growth; $13^{\text {th }}$ Five Year Plan, 2016-2020), but China remains some way from regulating a 'reference level' of good practice in relation to DWPA in its diverse farming systems. This generic aim can be usefully drawn from Figure 2 and international examples, but the actual regulatory regime must be unique to Chinese conditions. Regulation of the farming sector is not yet highly politicised and any resistance may be low and lack organisation, but small farm scales and incomes may limit the compliance-related costs that can be imposed before many remaining smallholders are forced out of markets (FORHEAD, 2014).

Other leading constraints to better farm regulation are institutional density, communication, data sharing and coordination gaps across agencies (including Ministries), the diversity of China's physical geography and farming systems, available resources for monitoring and enforcement, and the sheer number of small farms. For example, regulations issued by central and provincial governments are monitored and enforced by local governments that tend to prioritise production and growth (Smith and Siciliano, 2015). Varied and partly overlapping responsibilities for regulating soil and water quality are spread across the Ministry of Environmental Protection, the Ministry of Land Resources, the Ministry of Water Resources and the Ministry of Agriculture (World Bank, 2006; FORHEAD, 2014). Local conditions are often not well addressed by the poor functionality and lack of specificity of much environmental regulation (Wang and Wang, 2011); a lack of clarity in definition of rights and responsibilities leaving transposition to guidelines and enforcement at the discretion of local authorities (Smith and Siciliano, 2015). Constraints to publication and sharing of data are barriers to improvement in agency cooperation (Smith and Siciliano, 2015). Meta-data, sampling methods, and other strengths and weaknesses of different data sets are rarely made accessible to non-expert users or even expert users in other agencies and Ministries; in fact experts are often simply unaware of the data available outside their own organisation (FORHEAD, 2014). Public participation remains limited to a passive role of 'information provider' without effective influence on agency performance evaluation and decision making (Burns and Zhou, 2010).

Central policy has provided the impetus and framework for incentive payments schemes in China (Bennett, 2009), but the PLDL programme is indicative that demand for this approach may grow, at least among municipalities seeking to protect their water supply. Growing leisure activity and tourism, as provided for example by Lake Tai, also increasingly provide drivers and potential financial resources for protection of water quality. Resistance to schemes may be low but weaknesses in the design and implementation of past schemes need to be avoided. Wide 
application of something like the CS scheme in England may be constrained by a lack of ideological consensus. Key tenets of Figure 2 - e.g. the 'polluter pays principle', a 'reference level' for farming practice, and targeting of incentive payments - may not yet be shared and accepted by a majority of stakeholders in China. Schemes need to be well adapted to Chinese conditions, locally varied (Zheng et al., 2013), and innovative in institutional arrangements to overcome resource constraints and resolve regional administrative and property rights issues over crossboundary ecosystem service provision (Bennett, 2009). To be significant in mitigating DWPA at national scale, schemes may need to be developed for large areas and for large numbers of farms.

Table 3 suggests that there are fewer constraints to drawing lessons from international experience to improve the effectiveness of advice provision and voluntary action in mitigation of DWPA. The PAES is relatively well resourced and has a clear and hierarchical institutional structure. There is potential to reform its priorities, ethos and modes of working to promote environmental protection alongside productivity in farming. It also has the potential to coordinate and quality assure other actors' activities within the increasing diverse AKIS developing in China. Workshops and field visits revealed, however, that this will require significant reorientation and training for staff and managers at all levels. They also revealed that the trust held by farmers in the PAES needs improvement, and hence lessons can be learnt from adviser accreditation schemes such as the FACTS in the UK. In comparison to England, it is also notable that China lacks the NGOs that have played a key role in mediation between state and farmers and in advice provision for mitigation of DWPA. There is also scope for lesson drawing to inform efforts to improve the knowledgebase for mitigation of DWPA in China. In England, information resources in the form of manuals and databases, experience of public participation, the demonstration test catchment programme and catchment modelling methods all provide examples to inform efforts in China seeking to apply its growing research outputs in coherent support of environmental protection policy.

\section{Conclusions: a mitigation framework for diffuse water pollution from agriculture for China}

Drawing on Figure 2, Table 3 and analysis above, a focus on three policy approaches to mitigate DWPA in China can be recommended. First is the need for targeted regulation of specific farm units. Laws are already in place to control DWPA but transposition of these into binding regulations at a provincial and local level is weak, whilst monitoring and enforcement is difficult to achieve given the vast number of farms and characteristics of DWPA. Although the Ministry of Environmental Protection is leading actions to improve the national monitoring system for ecology and environment by 2020, resources for monitoring and enforcement remain limited and some targeting is required. For example, experience in England and the wider EU suggests that, given their relatively small number yet high potential to cause significant pollution loads, intensive livestock units (e.g. pork and poultry production) can be effectively targeted with regulation. China already has regulations which apply to the livestock sector and it is suggested that steps are taken to ensure these regulations are well-focused on mitigation of DWPA and are adequately enforced. Effective enforcement should be possible given the relatively small number of large livestock rearing units when compared to the total number of farms in China as a whole. In contrast, given limitations for their enforcement, manure and chemical fertiliser management regulations for arable crops are best left as guidelines and addressed through a voluntary and advisory approach developed by the PAES and its AKIS partners. However, as land transfer continues at a pace appropriate to local conditions and an increasingly dualistic structure of farming develops there can be ambition to develop a reference level of enforceable regulation for all large commercial farms.

Second, targeted incentive payment schemes can be used strategically to protect water resources from DWPA. Payments would be offered to farmers in designated locations, for example, vulnerable land adjacent to watercourses or in recharge zones of aquifers used for water supply. Payment would facilitate conversion of land out of intensive agricultural production to low intensity farming or other land use with lower risk of pollutant emissions. Although China has considerable experience there is scope for lesson drawing for the modalities of such schemes from England and 
other countries. For example, transfer of methods to ensure cost effectiveness such as spatial risk mapping and modelling to identify land within a river basin with the most potential to buffer water resources from DWPA. Such zones often occupy land that is marginal for food production (and increasingly for mechanisation given growing labour constraints in some farming systems). Hence impacts on food security may be acceptable, and payment rates relatively affordable if based on opportunity costs of production foregone (cognisant of rural income concerns or resettlement needs). For example, the SLCP only reduced grain supply by $2-3 \%$ in the upper reaches of the Yangtze and Yellow Rivers (Feng et al., 2005). International lesson drawing may also inform payment regimes that ensure long-term land use change and prevent reversion. For this, payments need to be sustained over a sufficient time frame to enable farmers to obtain alternative income streams or resettle in different zones (migrants will require transitional support for successful resettlement). Objective and transparent approaches are needed to help reduce potential disputes between local governments over assessment methods and compensation rates.

Third, a relatively well resourced PAES exists to help farmers maintain and increase agricultural productivity which can be re-oriented and re-skilled for environmental protection. There are weaker constraints to lesson drawing from abroad to inform this. The need is to rebalance the importance of productivity alongside the stewardship of farm inputs, natural resources and wider environmental protection. Farm advice should emphasize resource use efficiency, profit maximisation and environmental protection alongside the goal of high productivity. It should increasingly address farms as businesses, looking beyond yields to the objectives of the business and management of costs, labour use, crop residues and animal wastes, marketing and supply chains and environmental impacts. Advice and training modes should become more differentiated by farm size, management type and cropping system. Similarly, a greater diversity of communication and education methods should be employed, matched to the needs and access of different farmer types, and also targeting wider public awareness of environmental quality and food safety. The PAES is a key resource for delivery, but also for coordination and quality control of other AKIS actors. Farm advice needs to be coordinated and consistent with DWPA mitigation strategies for defined farm types, cropping systems and areas; even if that advice is delivered in future via multiple public and private sector pathways. The advice and continuing research needs to be tailored to farmers' needs and informed by their participation and a two-way dialogue. Closer interagency working, with improved communication and data sharing at all levels, are required to develop the new ethos and overcome barriers to coordination created by functional divisions and specialisations. A major challenge is that this re-orientation is needed from the highest levels of the Ministry of Agriculture and across staff and managers in regional and local government.

Support should be given to emerging farmer associations and cooperatives, whilst large agroenterprises should be well-regulated but also assisted and utilised as demonstrations of best practice. Amalgamation of farms through land transfer offers growing efficiencies of scope and scale for provision of advice and technology transfer (also for implementation of incentive payments schemes). In England experienced and innovative farmers are part of the AKIS and a resource to be used for environmental protection. Small farmers in China are experienced but often ageing and poorly educated. However, a cadre of skilled managers of larger agro-enterprises is growing rapidly and provides a potential resource for innovation, practice and demonstration in pursuit of environmental protection. To support and facilitate each of the three approaches identified here, investment is needed in applied research to build an accessible knowledgebase. Citing leading examples, this knowledgebase must span from methods for public participation, through design and costing of farm best management practices and design of institutional mechanisms for incentive payments, to estimation of modelling coefficients empirically derived for conditions in China.

\section{Acknowledgements:}

This research has been conducted under the 'PPM-Nutrients: Knowledge, policy and practice for sustainable nutrient management and water resources protection in UK and Chinese agroecosystems' Project, funded by Defra (SCF0302) and Ministry of Agriculture China (948 project, 
2015-Z7), under the Sustainable Agriculture Innovation Network (SAIN). The assistance of farmers, officials and other informants in the locations studied in China is also gratefully acknowledged. Also the support and contributions provided by other colleagues at: AgroEnvironmental Protection Institute, Ministry of Agriculture, Tianjin; College of Resources and Environmental Sciences, China Agricultural University, Beijing; College of Natural Resources and Environment, Northwest A\&F University, Yangling, PRC.

\section{References:}

AIC, 2013. AIC Value of Advice Report, Agricultural Industries Confederation, April 2013. https://www.agindustries.org.uk/latest-documents/value-of-advice-project-report/, accessed $18^{\text {th }}$ May 2016.

BASIS. 2016. About FACTS. BASIS Registration Ltd. http://www.basisreg.co.uk/Schemes/FACTS/About-FACTS, accessed 31 ${ }^{\text {st }}$ May 2016.

Bennett, MT. 2009. Markets for Ecosystem Services in China: An Exploration of China's "Ecocompensation" and Other Market-Based Environmental Policies. Forest Trends, http://www.foresttrends.org/documents/files/doc_2317.pdf, accessed 19 ${ }^{\text {th }}$ May 2016.

Benson, D. 2009. Review article: constraints on policy transfer, CSERGE Working Paper, EDM 0913, School of Environmental Sciences, University of East Anglia.

Benson, D., Jordan, A. 2011. What have we learnt from policy transfer research? Dolowitz and Marsh revisited, Political Studies Review 9, 3, 366-378.

Burns, JP., Zhou, Z. 2010. Performance Management in the Government of the People's Republic of China: Accountability and Control in the Implementation of Public Policy. OECD Journal on Budgeting, 10, 2, 1-28.

Cao, S., Chen, L., Yu, X. 2009. Impact of China's Grain for Green Project on the landscape of vulnerable arid and semiarid agricultural regions: a case study in northern Shaanxi Province. J. Appl. Ecol. 46, 536-543.

CEC. 1991. Council Directive 91/676/EEC of 12 December 1991 concerning the protection of waters against pollution caused by nitrates from agricultural sources, Commission of the European Communities, Brussels.

CEC. 2000. Directive 2000/60/EC of the European Parliament and the Council of 23 October 2000 Establishing a Framework for Community Action in the Field of Water Policy, Commission of the European Communities, Brussels.

Chen, G., 2011. China's Agricultural Subsidies: Policy Design and Alternatives. China Development Press, Beijing.

Chen, X. et al. 2014. Producing more grain with lower environmental costs. Nature, 514, 486-489.

China Water Risk, 2015. 2014 State of Environment Report Review, http://chinawaterrisk.org/resources/analysis-reviews/2014-state-of-environment-report-review/, accessed 17 August 2015.

Choi, I., 2006. Global climate change and the use of economic approaches: the ideal design features of domestic greenhouse gas emissions trading with an analysis of the European Union's CO2 emissions trading directive and the climate stewardship act. Natural Resources Journal 45, 4, 865-952. 
Curry, N., Ingram, J., Kirwan, J., Maye, D., 2012. Knowledge networks for sustainable agriculture

Cuttle, SP., Newell-Price, JP., Harris, D., Chadwick, DR., Shephed, MA., Anthony, SGA., Macleod, CJA., Haygarth, PM., Chambers, BJ., 2016, A method-centric 'User Manual' for the mitigation of diffuse water pollution from agriculture, Soil Use and Management, 32, 162-171.

Defra, 2012. An overview of the Local Nature Partnership role. April 2012. Department for Environment, Food and Rural Affairs.

Defra and The Rivers Trust, 2012. Defra Strategic Evidence and Partnership Project, Defra and The Rivers Trust.

Defra, 2013a. Review of Environmental Advice, Incentives and Partnership Approaches for the Farming Sector in England: Evaluation of selected advice and incentives schemes, March 2013, Department for Environment, Food and Rural Affairs.

Defra, 2013b. Farming Regulation Task Force Implementation: Earned Recognition Plan, August 2013, Department for Environment, Food and Rural Affairs.

Defra, 2013c. Catchment Based Approach: Improving the quality of our water environment: A policy framework to encourage the wider adoption of an integrated Catchment Based Approach to improving the quality of our water environment. May 2013, Department for Environment, Food and Rural Affairs.

Defra, 2015a. Campaign for the Farmed Environment - Survey of land managed voluntarily in the 2014/15 farming year (England), June 2015, Department for Environment, Food and Rural Affairs.

Defra, 2015b. Farming Statistics Provisional 2015 cereal and oilseed rape production estimates United Kingdom, October 2015, Department for Environment, Food and Rural Affairs.

Defra, 2016. The guide to cross compliance in England 2016. Rural Payments Agency, Department for Environment, Food and Rural Affairs.

Dolowitz, DP., Marsh, D. 1996. Who Learns What From Whom? A Review of the Policy Transfer Literature, Political Studies, XLIV, 343-357.

Dolowitz, DP., Marsh, D. 2000. Learning from Abroad: The Role of Policy Transfer in Contemporary Policy-Making, Governance 13, 1, 5-23.

ECEGP, 2015. Action Plan for Water Pollution Prevention, State Council of the People's Republic of China, 2 April 2015, English Translation by EU - China Environmental Governance Programme, May 2015, www.ecegp.com.

Economist, 2014. Green teeth: The government amends its environmental law. The Economist, May 17 th 2014.

EU SCAR, 2012, Agricultural knowledge and innovation systems in transition - a reflection paper, Brussels.

Evans, M. 2009. 'Policy Transfer in Critical Perspective', Policy Studies 30, 3, 243-268.

Feng, Z., Yang, Y., Zhang, Y., Zhang, P., Li, P. 2005. Grain for green policy and its impacts on grain supply in west China, Land Use Policy 22, 301-312. 
FORHEAD, 2014. Food Safety in China: A Mapping of Problems, Governance and Research. Forum on Health, Environment and Development (FORHEAD), Working Group on Food Safety.

Garforth, C., Angell, B., Archer, J., and Green, K., 2003. Fragmentation or creative diversity? Options in the provision of land management advisory services, Land Use Policy, 20, 4, 323-333.

Gov.UK, 2016a. River Basin Management Plans 2015, https://www.gov.uk/government/collections/river-basin-management-plans-2015, accessed $17^{\text {th }}$ May 2016.

Gov.UK, 2016b, Countryside Stewardship: statements of priorities, https://www.gov.uk/government/collections/countryside-stewardship-statements-of-priorities, accessed $17^{\text {th }}$ May 2016.

Gov.UK, 2016c. Farming Advice Service, https://www.gov.uk/government/groups/farming-adviceservice, accessed $6^{\text {th }}$ May 2016.

He, J. and Sikor, T. 2015. Notions of justice in payments for ecosystem services: Insights from China's Sloping Land Conversion Program in Yunnan Province, Land Use Policy, 43, 207-216.

Holden, J., Haygarth, P., MacDonald, J., Jenkins, A., Sapiets, A., Orr, H., Dunn, N., Harris, B., Pearson, P., McGonigle, D., Humble, A., Ross, M., Harris, J., Meacham, T., Benton, T., Staines, A., and Noble, A., 2016. Agriculture's Impacts on Water Quality, Global Food Security and the UK Water Partnership.

Hu, RF., Yang, ZJ., Kelly, P., Huang, JK., 2009. Agricultural extension system reform and agent time allocation in China. China Econ. Rev. 20, 303-315.

Huan, Y., Gao, X., Li, J., 2010. Farmer cooperation and organization: new challenges, new networks, new identities, in: Song Y., Vernooy, R. (Eds.), Seeds and Synergies. Practical Action Publishing, Rugby, pp.65-84.

Huang, J., Wang, X., Qui, H., 2012. Small-scale farmers in China in the face of modernisation and globalisation. IIED/HIVOS, London/The Hague.

Huang, J., 2014. Personal communication. Director and Professor, Center for Chinese Agricultural Policy, Chinese Academic of Sciences.

Knierim, A. and Prager, K., 2015. Agricultural Knowledge and Information Systems in Europe: Weak or Strong, Fragmented or Integrated?

http://www.proakis.eu/sites/www.proakis.eu/files/AKIS_characterisation_briefing_final.pdf, accessed $18^{\text {th }}$ May 2016.

Lally, B., Riordan, B. and van Rensburg, T., 2007. Controlling Agricultural Emissions of Nitrates: Regulations versus Taxes, Working Paper No. 0122, Department of Economics, National University of Ireland, Galway. http://hdl.handle.net/10379/955, accessed 31 ${ }^{\text {st }}$ May 2016.

Law Commission, 2013. Conservation Covenants: A Summary, Consultation Paper No 211 (Summary), The Law Commission, 28 March 2013.

Law Commission, 2014. Conservation Covenants, Law Com No 349, The Law Commission, HMSO. 
Law Commission, 2016. Conservation Covenants: Current project status, The Law Commission, http://www.lawcom.gov.uk/project/conservation-covenants/, accessed $18^{\text {th }}$ May 2016.

Li., Y., Zhang, W., Ma, L., Huang, G., Oenema, O., Zhang, F., Dou, Z., 2013. An Analysis of China's Fertilizer Policies: Impacts on the Industry, Food Security, and the Environment. Journal of Environmental Quality, 42, 972-981.

Ma, L., Zhang, W., Ma, W., Velthof, G., Oenema, O., Zhang, F, 2013. An Analysis of Developments and Challenges in Nutrient Management in China, J. Environ. Qual. 42, 951-961.

Marquis, C., Zhang, J., Zhou, Y., 2011. Regulatory Uncertainty and Corporate Responses to Environmental Protection in China, California Management Review, 54, 1, 39-63.

Mauerhofer, V., Hubacek, K., Coleby, A. 2013. From polluter pays to provider gets: distribution of rights and costs under payments for ecosystem services. Ecology and Society 18, 4, Art. 41.

McGonigle, DF., Burke, SP., Collins, AL., Gartner, R., Haft, MR., Harris, RC., Haygarth, PM., Hedges, MC., Hiscock, KM., Lovett, AA., 2014, Developing Demonstration Test Catchments as a platform for transdisciplinary land management research in England and Wales, Environ. Sci.: Processes Impacts, 16, 1618-1627.

McKenney, BA., Kiesecker, JM., 2010. Policy Development for Biodiversity Offsets: A Review of Offset Frameworks, Environmental Management, 45, 165-176.

MEP, 2010. Bulletin of National Environmental Statistics 2009, Ministry of Environmental Protection, Beijing.

NAO, 2012. Streamlining Farm Oversight, December 2012, National Audit Office.

NE, 2015. Countryside Stewardship Manual, November 2015, Natural England, Department for Environment, Food and Rural Affairs.

Newell Price, JP., Harris, D., Taylor, M., Williams, JR., Anthony, SG., Duethmann, D., Gooday, RD., Lord, El., Chambers, BJ., Chadwick, DR., Misselbrook, TH., 2011. An Inventory of Mitigation Methods and Guide to their Effects on Diffuse Water Pollution, Greenhouse Gas Emissions and Ammonia Emissions from Agriculture, Defra Project WQ0106, Department for Environment, Food and Rural Affairs.

Ni, H., 2013. Agricultural Domestic Support and Sustainable Development in China. ICTSD Programme on Agricultural Trade and Sustainable Development, Issue Paper No. 47. International Centre for Trade and Sustainable Development, Geneva.

OECD 2010. Guidelines for Cost-effective Agri-environmental Policy Measures, OECD Publishing, Paris.

OECD, 2011. China - Agricultural Policy Monitoring and Evaluation. OECD Publishing, Paris.

OECD 2012. Water Quality and Agriculture: Meeting the Policy Challenge, OECD Studies on Water, OECD Publishing, Paris.

Powers, SM., Bruulsema, TW., Burt, TP., Neng long Chan, Elser, JJ., Haygarth, PM., Howden, NJK., Jarvie, HP., Yang Lyu, Peterson, HM., Sharpley, AN., Jianbo Shen, Worrall, F., Fusuo Zhang. 2016. Long-term accumulation and transport of anthropogenic phosphorus in three river basins, Nature Geoscience, published online: 11 April 2016, DOI: 10.1038/NGEO2693 
Powlson, D., Norse, D., Chadwick, D., Lu, Y., Zhang, W., Zhang, F., Huang, J., Jia, X. 2014. Contribution of improved nitrogen fertilizer use to development of a low carbon economy in China, World Agric. 4, 10-18.

Prager, K., Thomson, K., 2014. AKIS and advisory services in the United Kingdom. Report for the AKIS inventory (WP3) of the PRO AKIS project. Online resource:

www.proakis.eu/publicationsandevents/pubs, accessed $6^{\text {th }}$ May 2016.

Rahn, CR. 2013. The Challenges of Knowledge Transfer in Implementation of the Nitrates Directive. NUTRIHORT - Nutrient management, innovative techniques and nutrient legislation in intensive horticulture for an improved water quality. Proceedings, 16th to 18th September 2013, Ghent.

Randall, NP., Donnison, LV., Lewis, PJ., James, KL., 2015. How effective are on-farm mitigation measures for delivering an improved water environment? A systematic map, Environmental Evidence, 4, 18.

Rose, R. 2005. Learning from Comparative Public Policy: A Practical Guide. Routledge, London.

RPA, 2016. Basic Payments Scheme: rules for 2016. Rural Payments Agency.

SAIN, 2016, China-UK Sustainable Agriculture Innovation Network (SAIN), http://www.sainonline.org/english.html, accessed $27^{\text {th }}$ July 2016.

Scheele, M. 1999. Environmental services provided by agriculture: The setting of environmental targets and reference levels, Conference Paper, 'Non-Trade Concerns in a Multifunctional Agriculture', Gran, Norway.

Shortle, J., Horan, R. 2001. The economics of nonpoint pollution control, Journal of Economic Surveys, 15, 3, 255-289.

Smith, L., 2013, Land Conservation Agreements, in Smith, S., Rowcroft, P., Everard, M., Couldrick, L., Reed, M., Rogers, H., Quick, T., Eves, C. and White, C., Payments for Ecosystem Services: A Best Practice Guide. Defra, London, pp. 65-67.

Smith, L., Porter, K. 2010. Management of Catchments for the Protection of Water Resources: Drawing on the New York City Watershed Experience, Regional Environmental Change 10, 4, 311326.

Smith, L., Siciliano, G. 2015. A comprehensive review of constraints to improved management of fertilizers in China and mitigation of diffuse water pollution from agriculture, Agric. Ecosyst. Environ, 209, 15-25.

Smith, L., Inman, A, and Cherrington, R., 2012. The Potential of Land Conservation Agreements for Protection of Water Resources, Environmental Science and Policy, 24, 92-100.

Smith, L., Porter, K., Hiscock, K., Porter, MJ., Benson, D. (Ed.) 2015a. Catchment and River Basin Management: Integrating Science and Governance, Earthscan Studies in Water Resource Management, Routledge, Abingdon and New York.

Smith, L., Siciliano, G., Inman, A., Rahn, C., Bellarby, J., Surridge, B., Haygarth, P., Xin, L., Guilong, Z., Ji, L., Zhou, J., Meng, F. and Burke, S. (2015b), Delivering improved nutrient stewardship in China: the knowledge, attitudes and practices of farmers and advisers. SAIN Policy Brief 13, UK-China Sustainable Agricultural Innovation Network (SAIN). http://www.sainonline.org/english.html, accessed $20^{\text {th }}$ May 2016. 
1033

1034

1035

1036

1037

1038

1039

1040

1041

1042

1043

1044

1045

1046

1047

1048

1049

1050

1051

1052

1053

1054

1055

1056

1057

1058

1059

1060

1061

1062

1063

1064

1065

1066

1067

1068

1069

1070

1071

1072

1073

1074

1075

1076

1077

1078

1079

1080

1081

1082

1083

1084

1085

1086

1087

Smith, S., Rowcroft, P., Everard, M., Couldrick, L., Reed, M., Rogers, H., Quick, T., Eves, C., White, C. 2013. Payments for Ecosystem Services: A Best Practice Guide. Defra, London.

Sun, B., Zhang, L., Yang, L., Zhang, F., Norse, D., Zhu, Z., 2012. Agricultural Non-Point Source Pollution in China: Causes, Mitigation Measures, Ambio, 41, 370-379.

Sutherland, LA., Mills, J., Ingram, R., Burton, R., Dwyer, G., Blackstock, KL., 2013. Considering the Source: Commercialisation and trust in agri-environmental information and advisory services in England, Journal of Environmental Management 118, 96-105.

Upstream Thinking, 2016. Upstream Thinking, http://www.upstreamthinking.org/, accessed $27^{\text {th }}$ May 2016.

Vorosmarty, CJ., Mclntyre, PB., Gessner, MO., Dudgeon, D., Prusevich, A., Green, P., Glidden, S., Bunn, SE., Sullivan, CA., Reidy Liermann, C., Davies, PM. 2010. Global threats to human water security and river biodiversity. Nature, 467, 555-561.

Wang, J., Wang, M., 2011. Environmental Rule of Law in China: Why the system isn't working, in Keeley, J., Yisheng, Z. (Eds.), 2011. Green China: Chinese insights on environment and development. International Institute for Environment and Development, London, pp.160-171.

Weersink, A. and Livernois, J. 1996. The use of economic instruments to resolve water quality problems from agriculture, Canadian Journal of Agricultural Economics 44, 345-353.

World Bank, 2006. China water quality management : Policy and institutional considerations. The World Bank, Washington, D.C.

Wunder, S., Engel, S. and Pagiola, S. 2008. Taking stock: A comparative analysis of payments for environmental services programs in developed and developing countries. Ecological Economics $65,834-852$.

WRT, 2006. Cornwall Rivers Project: Final Report of Project Activities, Westcountry Rivers Trust. http://www.cornwallriversproject.org.uk/downloads/end_project_brochure.pdf, accessed $31^{\text {st }}$ May 2016.

Xiaoyun, L., Dongmei, W., Leshan, J., Ting, Z. 2006. Impacts of China's agricultural policies on payment for watershed services. College of Humanities and Development, China Agricultural University and International Institute for Environment and Development, London.

Xu, ZG., Bennett, MT., Tao, R., Xu, JT. 2004a. China's sloping land conversion program four years on: current situation and pending issues. International Forestry Review 6, 3-4, 317-326.

Xu, JT., Tao, R., Xu, ZG. 2004b. Sloping land conversion: cost effectiveness, structural adjustment, and economic sustainability. China Economics Quarterly, 4, 1, 139-162.

Xu, J., Yin, R., Li, Z., Liu, C. 2006. China's ecological rehabilitation: unprecedented efforts, dramatic impacts and requisite policies. Ecol. Econ. 57, 595-607.

Zhen, L., Zhang, H. 2011. Payment for Ecosystem Services in China: An Overview, Living Rev. Landscape Res., 5, 2, accessed $19^{\text {th }}$ May 2016, http://www.livingreviews.org/lrlr-2011-2

Zheng, H., Robinson, BE., Liang, Y., Polasky, S., Mae, D., Wange, F., Ruckelshaus, M., Ouyanga, Z., Daily, GC. 2013. Benefits, costs, and livelihood implications of a regional payment for ecosystem service program, PNAS, 110, 41, 16681-16686. 
Figure 1: Stages of lesson drawing.

\section{DEMAND SIDE}

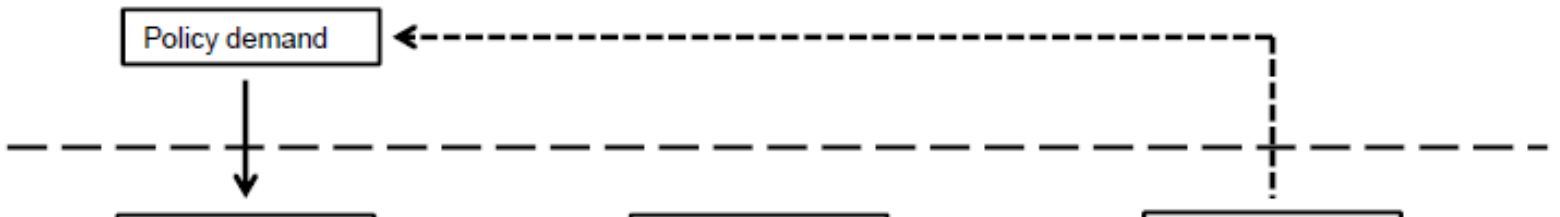

Understanding the 'exporting

Understanding

Application of the

jurisdiction'

the 'importing

policy or lesson

1090

1091

1092

SUPPLY SIDE

Source: Benson, 2009. 


\section{Constraints \\ Key questions}

Demand side constraints:

Policy demand

Policy resistance

Context/jurisdiction constraints:

Path dependency

Existing structures

Political context

Resources

Ideological consensus

Application constraints:

Programmatic uniqueness

Programmatic complexity

Institutional comparability

Scale of change

Programmatic modification enabling? enabling? divergence?
Is there demand for the policy or programme?

Is there potential resistance to lesson High/low resistance drawing and policy change?

Are past policies restrictive or

Are existing structures restrictive or

Is politicisation apparent?

Are resources adequate to support transfer in the receiving context? Is there ideological consistency or

How unique is the policy?

How complex is the policy?

Will new institutions be needed?

What scale of change is anticipated? Are policy/programme adjustments needed?

\section{Indicators}

High/low demand

High/low path dependency

High/low structural density

High/low politicisation

Inadequate/adequate

resources

Divergence/consistency

Unique/generic

High/low complexity

Disabling/enabling institutional conditions

Large/small scale change

High/low programme adjustment needed for transfer

Source: adapted from Benson 2009; Dolowitz and Marsh, 2000. 
1096

1097

Figure 2: A mitigation framework for diffuse water pollution from agriculture

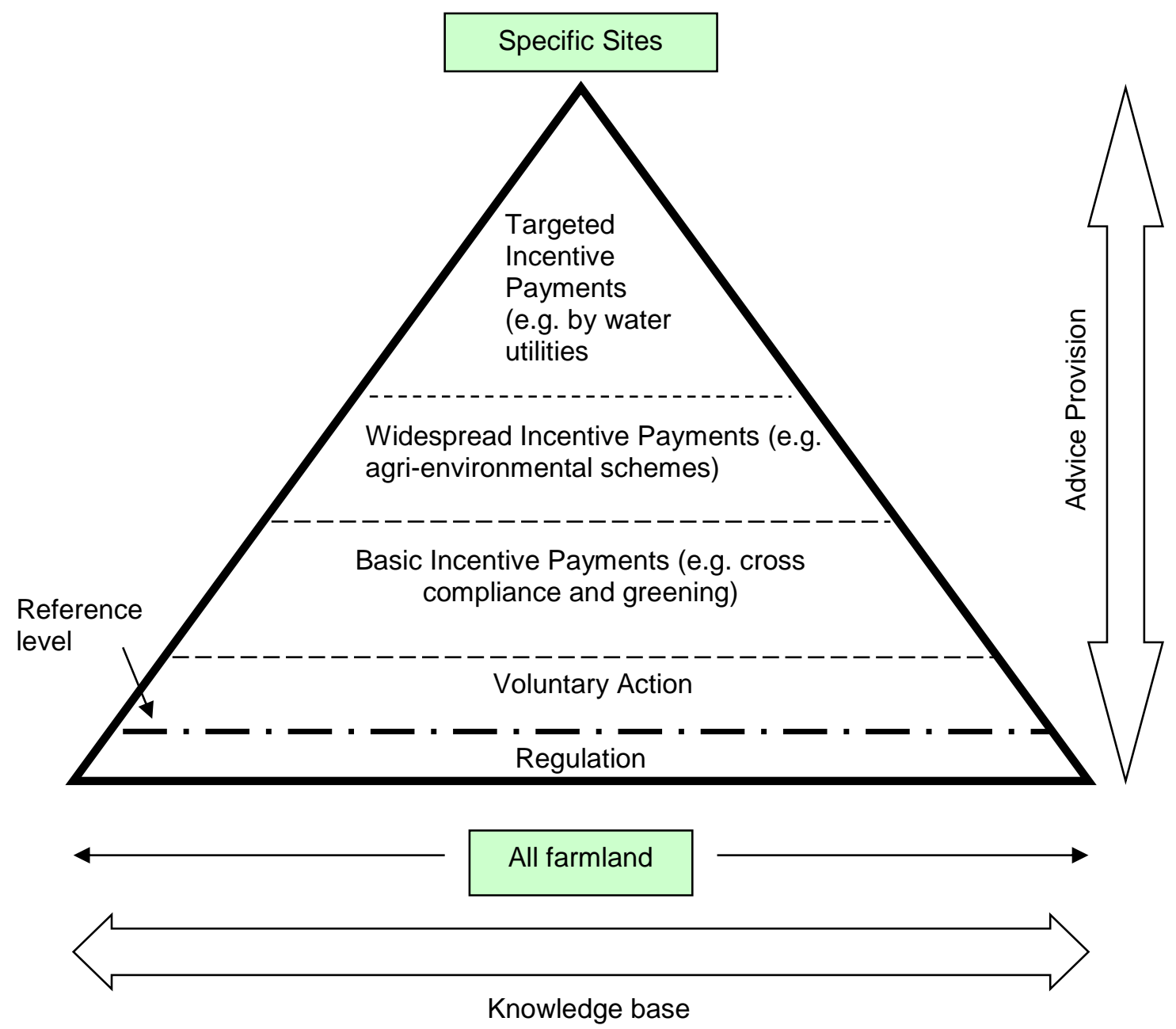


Table 2: Farm inspections in England relevant to mitigation of diffuse water pollution from agriculture, 2011-2012

\begin{tabular}{|c|c|c|c|c|}
\hline Agency & Purpose & $\begin{array}{l}\text { Number of } \\
\text { inspections }\end{array}$ & Comment & $\begin{array}{l}\text { Potential for an } \\
\text { 'earned recognition' } \\
\text { approach }\end{array}$ \\
\hline $\begin{array}{l}\text { Environment } \\
\text { Agency }\end{array}$ & $\begin{array}{l}\text { Environmental } \\
\text { protection } \\
\text { (catchment } \\
\text { related) }\end{array}$ & 700 & $\begin{array}{l}\text { decreasing as } \\
\text { information is } \\
\text { gained }\end{array}$ & moderate \\
\hline $\begin{array}{l}\text { Environment } \\
\text { Agency }\end{array}$ & $\begin{array}{l}\text { Water resource } \\
\text { protection }\end{array}$ & 2000 & risk-based & moderate \\
\hline $\begin{array}{l}\text { Rural } \\
\text { Payments } \\
\text { Agency }\end{array}$ & $\begin{array}{l}\text { Cross- } \\
\text { compliance } \\
\text { inspection }\end{array}$ & $\begin{array}{l}1,700: 1 \% \text { of the } \\
\text { claimants at } \\
\text { minimum }\end{array}$ & $\begin{array}{l}20 \%-25 \% \\
\text { selected by } \\
\text { random, } \\
\text { others by risk }\end{array}$ & $\begin{array}{l}\text { moderate to good } \\
\text { (referring participation } \\
\text { in voluntary farm } \\
\text { assurance schemes) }\end{array}$ \\
\hline $\begin{array}{l}\text { Rural } \\
\text { Payments } \\
\text { Agency }\end{array}$ & $\begin{array}{l}\text { Environmental } \\
\text { Stewardship } \\
\text { scheme } \\
\text { eligibility } \\
\text { inspection }\end{array}$ & $\begin{array}{l}2,500: 5 \% \text { of } \\
\text { beneficiaries within } \\
5 \text { years of } \\
\text { agreement and } \\
2.5 \% \text { of those over } 5 \\
\text { years at minimum }\end{array}$ & $\begin{array}{l}20 \%-25 \% \\
\text { selected at } \\
\text { random, } \\
\text { others by risk }\end{array}$ & $\begin{array}{l}\text { good where based on } \\
\text { past performance in the } \\
\text { scheme }\end{array}$ \\
\hline
\end{tabular}

1101

Source: Defra, 2013b

1102 
1103 Table 3: Assessment of lesson drawing for mitigation of diffuse water pollution from 1104 agriculture in China

\begin{tabular}{|c|c|c|c|}
\hline \multirow{3}{*}{$\begin{array}{l}\text { Constraints to lesson } \\
\text { drawing } \\
\text { Policy demand }\end{array}$} & \multicolumn{3}{|c|}{ Policy approaches } \\
\hline & Regulation & Incentive payments & $\begin{array}{l}\text { Advice provision/ } \\
\text { voluntary action }\end{array}$ \\
\hline & Growing demand & $\begin{array}{l}\text { Low but protection of } \\
\text { water for drinking } \\
\text { supplies and leisure } \\
\text { activity becoming a } \\
\text { driver. }\end{array}$ & $\begin{array}{l}\text { Lacks articulation from } \\
\text { the top-down; weak } \\
\text { from the bottom-up. }\end{array}$ \\
\hline Policy resistance & Low & Low & Low to moderate \\
\hline Path dependency & Low & Moderate & Low to moderate \\
\hline Existing structures & High structural density & High structural density & Low structural density \\
\hline Political context & Low politicisation & Moderate politicisation & Low politicisation \\
\hline Resources & Resources inadequate & $\begin{array}{l}\text { Inadequate beyond } \\
\text { water supply zones }\end{array}$ & Resources adequate \\
\hline Ideological consensus & Moderate consistency & Moderate consistency & Consistent \\
\hline $\begin{array}{l}\text { Programmatic } \\
\text { uniqueness }\end{array}$ & $\begin{array}{l}\text { Generic purpose but } \\
\text { unique in detail. }\end{array}$ & Unique programmes & $\begin{array}{l}\text { Generic purpose but } \\
\text { unique in detail. }\end{array}$ \\
\hline $\begin{array}{l}\text { Programmatic } \\
\text { complexity }\end{array}$ & High & High & Moderate \\
\hline $\begin{array}{l}\text { Institutional } \\
\text { comparability }\end{array}$ & Disabling & Disabling & Disabling \\
\hline Scales of change & $\begin{array}{l}\text { Potentially large in } \\
\text { scale. }\end{array}$ & Moderate to large & Small \\
\hline $\begin{array}{l}\text { Programmatic } \\
\text { modification }\end{array}$ & $\begin{array}{l}\text { Relatively low for } \\
\text { generic purpose, but } \\
\text { high for detail. }\end{array}$ & Relatively high & $\begin{array}{l}\text { Manageable and } \\
\text { iterative. }\end{array}$ \\
\hline
\end{tabular}

